\title{
The mediating effect of emotion regulation on the mindfulness and impulsivity of high school students
}

\author{
Karisa Elisabeth Lokita, ${ }^{1 *}$ Frieda Maryam Mangunsong Siahaan, ${ }^{1}$ Pratiwi Widyasari ${ }^{1}$ \\ ${ }^{1}$ Faculty of Psychology, Universitas Indonesia, Depok - Indonesia
}

\begin{abstract}
Impulsivity increases the risk of addiction and negatively affects academic performance. One-way high school students can manage impulsivity is through mindfulness skills, in which the relationship between mindfulness and impulsivity can be mediated by emotion regulation. This study aims to establish whether emotion regulation plays a mediating role in the relationship between mindfulness and impulsivity in high school students. Quantitative research was conducted through mediation analysis using Hayes' PROCESS program. The Mindfulness Attention Awareness Scale (MAAS) was used to measure mindfulness; impulsivity was measured using the Barratt Impulsiveness Scale 11 (BIS-11); and emotional dysregulation using the Difficulties in Emotion Regulation Scale (DERS). The participants were 390 high school students in Indonesia aged 15-18. The results show that emotion regulation partially mediated the relationship between mindfulness and impulsivity ( $\mathrm{ab}=-.11, \mathrm{SE}=0.02,95 \% \mathrm{CI}[-0.16,-0.07])$. Mindfulness was found to improve emotion regulation skills and reduce impulsivity in high school students. The implications of the study are important in helping adolescents manage impulsivity, as they are at an age that is prone to risk taking. The use of mindfulness in schools could help manage emotional and behavioral problems in adolescents at high school age.
\end{abstract}

Keywords: emotion regulation; high school students; impulsivity; mindfulness

\begin{abstract}
Abstrak: Impulsivitas meningkatkan risiko adiksi serta mempengaruhi kinerja akademis secara negatif. Salah satu cara siswa Sekolah Menengah Atas (SMA) dapat mengelola impulsivitas adalah dengan kemampuan mindfulness, dimana hubungan antara mindfulness serta impulsivitas dapat dimediasi oleh regulasi emosi. Penelitian ini bertujuan untuk melihat apakah regulasi emosi memiliki peran mediasi pada hubungan antara mindfulness dan impulsivitas siswa SMA. Riset kuantitatif dilakukan dengan analisis mediasi menggunakan program PROCESS milik Hayes. Mindfulness Attention Awareness Scale (MAAS) digunakan untuk mengukur mindfulness. Sementara impulsivitas diukur menggunakan Barratt Impulsiveness Scale 11 (BIS-11) dan disregulasi emosi menggunakan Difficulties in Emotion Regulation Scale (DERS). Partisipan adalah 390 siswa SMA di Indonesia yang berusia 15-18 tahun. Hasil menunjukkan bahwa regulasi emosi memediasi hubungan antara mindfulness dan impulsivitas secara partial $(\mathrm{ab}=-0,11, \mathrm{SE}=0,02, \mathrm{CI} 95 \%[-0,16$, -0,07]). Mindfulness ditemukan meningkatkan kemampuan regulasi emosi dan mengurangi impulsivitas pada siswa SMA. Implikasi dari studi ini penting untuk membantu remaja mengelola impulsivitas di usia yang rentan untuk mengambil risiko. Penggunaan mindfulness di sekolah dapat membantu mengelola permasalahan emosi dan perilaku pada remaja di usia SMA.
\end{abstract}

Kata Kunci: regulasi emosi; remaja SMA; impulsivitas; mindfulness

\footnotetext{
*Corresponding Author: Karisa Elisabeth Lokita (karisa.elisabeth91@ui.ac.id), Faculty of Psychology, Universitas Indonesia, Jl. Lkr. Kampus Raya Jl. Mawar No.5 38, Pondok Cina, Kecamatan Beji, Kota Depok 16424-Indonesia.
} 


\section{Introduction}

Adolescence can be a challenging time of life, during which young people are more inclined to take risks, make impulsive decisions, and lack inhibitory control due to the absence of maturity in their brain development (Marks \& Gelder, 1966). Sensation seeking, which is the tendency to pursue exciting activities and try new experiences that may be dangerous, also increases significantly during adolescence (Whiteside \& Lynam, 2001). It increases the opportunities for adolescents to display risky and impulsive behaviors (Romer, 2010). Adolescents at high school also face a difficult period because aspects of impulsivity such as acting without thinking and sensation-seeking peak at the age of 15-18 before decreasing during their 20s (Harden \& Tucker-Drob, 2011; Khurana et al., 2018). Some of these factors show that high school adolescents are prone to impulsivity.

Impulsivity is the tendency for individuals to act before they think, have difficulties focusing and concentrating on tasks, and act without forethought (Patton et al., 1995; Stanford et al., 2009). Impulsive individuals usually have difficulties controlling their impulses when they feel negative or positive emotions, known as negative and positive urgency (Whiteside \& Lynam, 2001). Individuals will choose to act impulsively to reduce their negative feelings or because they are overwhelmed with positive emotions. Impulsive individuals also lack premeditation, having the tendency to not think and reflect on the consequences of an action before taking it (Whiteside \& Lynam, 2001). Impulsive individuals also find it difficult to focus on or pay attention to a task, which refers to a lack of perseverance (Cyders et al., 2007; Whiteside \&
Lynam, 2001). Based on these characteristics, impulsive individuals tend to act automatically without full awareness or attention, spontaneously, and without considering the negative consequences of their actions (Levesque \& Brown, 2007; Patton et al., 1995; Stanford et al., 2009). Impulsive individuals are predisposed to react directly to experiences of the present moment (Murphy \& MacKillop, 2012).

Impulsivity in adolescents can predict risky and problematic behaviors during adulthood and adolescence itself, such as smoking, drinking alcohol, substance abuse, delinquency, and sexual activities (Cooper et al., 2003; D'Acremont \& Van Der Linden, 2005; Robbins \& Bryan, 2004; Schreiber et al., 2012). A study in Indonesia found that adolescents' tendency to think impulsively also increased aggressive behavior (Rahmawati \& Asyanti, 2017). Besides behavioral issues, impulsivity is also related to lower academic achievement (Lozano et al., 2014; Merrell \& Tymms, 2001; Spinella \& Miley, 2003; Vigil-Colet \& Morales-Vives, 2005). Valiente et al. (2013) suggest that impulsivity affects academic achievement negatively because it disturbs students' habits related to staying organized, concentrating on studying for a period of time, and their relationships with the people around them. In Indonesia, impulsive students also tend to commit academic dishonesty, such as cheating and plagiarism (Fawzia, 2019).

Impulsivity also plays a factor in the increase in internet addiction since the COVID-19 pandemic. Ever since the pandemic started, students' use of the internet and social media has increased, even up to the point of some suffering from internet addiction (Gómez-Galán et al., 2020; Ratulangi et al., 2021). Gecaite-Stonciene et al. 
(2021) found that problematic internet use is a form of impulsive coping behavior and that students with a higher impulsivity level tend to be addicted to the internet, which can lead to neglect of academic responsibility (Gómez-Galán et al, 2020). Indonesian adolescents are also vulnerable to this problem, as 30 million of them have internet access and around $80 \%$ of adolescents in big cities use the internet (Kepala Pusat Informasi dan Humas Kementerian Kominfo, 2014). Those with a higher level of impulsivity also have a higher tendency to suffer from internet addiction (Suhendar, 2019). Impulsive adolescents with lower levels of self-control have also been found to be more likely to be prone to impulsive buying, especially from online stores (Lesmana, 2017; Sari \& Handayani, 2019). This shows the importance of reducing impulsivity in adolescents.

Since impulsive adolescents have the tendency to act spontaneously without proper premeditation, acting with awareness and attention could prevent them from reacting spontaneously to present experiences. This in turn will help them control impulsive behaviors. This ability is known as mindfulness, which is "a receptive attention to and awareness of present events and experience" (Brown et al., 2007). Mindful individuals have full awareness of events happening at the present moment and process their experiences with acceptance and without judgment. They will also be aware that their thoughts, emotions, and impulses should solely be observed, without responding spontaneously or automatically. This process is known as deautomatization, which can increase present moment awareness and reduce impulsive behaviours (Levesque \& Brown, 2007).
Mindfulness has been found to have positive effects on adolescents, such as reducing the symptoms of mental health problems, reducing negative behaviors, and increasing resiliency (Aini et al., 2021; Carsley et al., 2018; Dunning et al., 2018; Franco et al., 2016; Vanzin et al., 2020). Salmoirago-Blotcher et al. (2019) even found that mindfulness could successfully reduce impulsivity in adolescents after they had received mindfulness training. This training was delivered for eight weeks during a health class, and by the end the reduction in impulsivity was larger than amongst students who had not received such training. Therefore, more mindful adolescents could have lower impulsivity.

Mindfulness and impulsivity both focus on the present moment, but with opposite emphases. Impulsivity refers to when individuals do not think of the long-term consequences of their actions (Murphy \& MacKillop, 2012). On the other hand, mindfulness is the process in which individuals are fully oriented towards the present moment, yet do not react to a stimulus (Murphy \& MacKillop, 2012). Individuals with mindfulness will be more aware of the present situation, and therefore have less chance to react automatically to impulses (Levesque \& Brown, 2007; Murphy \& MacKillop, 2012).

Peters et al. (2011) also suggest several ways in which mindfulness can reduce impulsivity. First, it increases individuals' awareness of present experiences, which facilitates the monitoring of impulses. Being able to notice impulsive tendencies already facilitates individuals' higher self-control (Peters et al., 2011). This might also positively affect adolescents' impulsivity, since Lesmana (2017) found that those who had the tendency to impulsively shop 
online usually did not act with awareness and therefore lacked self-control. Second, mindfulness can also reduce impulsivity through the decrease in experiential avoidance, which is individuals' unwillingness to process and face distressing internal experiences (Peters et al., 2011). Individuals with experiential avoidance tend to act impulsively as a way to escape from negative thoughts or feelings. Mindfulness training promotes the acceptance of unpleasant experiences without judgment, which reduces the tendency to act impulsively (Peters et al., 2011). Therefore, mindfulness can help reduce impulsive urges in adolescents, as has been demonstrated in several other studies (Lesmana, 2017; Murphy \& MacKillop, 2012; Park \& Dhandra, 2017; Williams \& Grisham, 2012)

Even though the association between mindfulness and impulsivity exists conceptually, some studies have made different findings (Korponay et al., 2019; Soler et al., 2016). Mindfulness-based training conducted by Korponay et al. (2019) showed that mindfulness could increase aspects of impulsivity related to attention and concentration, but failed to reduce other aspects of impulsivity, such as the control of actions without thinking and long-term planning. Similar results were found by Soler et al. (2016), when mindfulness-based training did not have a significant effect on reducing impulsivity. Hence, there is a possibility that another variable facilitates the relationship between mindfulness and thinking before acting, because simply increasing the attention paid to the present moment may not be sufficient.

One of the benefits of mindfulness is the increase in emotion regulation. This is the ability to be aware of and to understand emotions; to accept them; to control impulsive behaviors; and to take goal-directed actions when feeling negative emotions, using strategies that are accurate and flexible in managing emotional responses to the needs of the situation (Gratz \& Roemer, 2004). Effective emotion regulation focuses on the ability to manage negative emotions effectively, and not to suppress or erase them (Luberto et al., 2014). This ability can be gained through mindfulness. Mindful individuals only observe their internal experiences and do not reactively judge the emotions they are feeling. They are more willing to face up to unpleasant experiences (Roemer et al., 2015). Mindfulness also causes decentring, or a more detached and less reactive view of emotions. In this way, individuals will be more able to use correct strategies to manage their emotions (Coffey \& Hartman, 2008).

Emotion regulation is also related with impulsivity. Impulsive individuals have difficulty regulating their emotions, such as the inability to accept negative emotions, difficulties in controlling impulses and understanding their emotions, and a lack of strategies for effective emotion regulation (Williams \& Grisham, 2012). Individuals also tend to act impulsively because of difficulties in managing negative emotions, also known as negative urgency (Gratz \& Roemer, 2004; Whiteside \& Lynam, 2001). Individuals who can manage their negative emotions better will use healthier coping mechanisms and display fewer impulsive coping behaviours, such as avoidance (Cooper et al., 2003; Schreiber et al., 2012). The same also applies to individuals who have difficulties in managing positive emotions. For example, people who are very happy might purchase products impulsively, even though they 
do not need them (Park \& Dhandra, 2017; Whiteside \& Lynam, 2001).

Difficulty in regulating emotions also predicts worse inhibitory responses because of the increase in negative emotions and the tendency to ruminate. Such individuals find it harder to pay attention, think before acting, and practice selfcontrol, which are all important aspects of impulsivity (King, 2020). Impulsive individuals also lack premeditation and can experience negative emotions more often, such as anger and sadness (Sperry et al., 2016). Another aspect of impulsivity that is connected to emotion regulation is the lack of perseverance, or difficulty in concentrating on tasks. Emotion regulation can increase individuals' attention to tasks because it involves the capacity to control their actions and concentrate on a goaldirected task (Gratz \& Roemer, 2004). Regulating emotions better will increase concentration on tasks and reduce the possibility of impulsive behaviors (Schreiber etal., 2012).

Emotion regulation is linked with both mindfulness and impulsivity and can play an important role in mediating their relationship. Individuals with a good capacity for mindfulness have awareness and pay attention to the present moment, which in turn increases their capacity to process internal experiences (Brown \& Ryan, 2003; Coffey \& Hartman, 2008). They are more aware of feelings and situations in the present moment, and act with acceptance and without judgment (Levesque \& Brown, 2007). Individuals who can accept unpleasant experiences will regulate their emotions better and use more effective coping strategies. This will have a positive effect on impulsive individuals, because they tend to act impulsively when they cannot manage negative or positive emotions (Whiteside \& Lynam, 2001).
A mechanism similar to this can also be applied to adolescents, who will also experience the same tendency to react spontaneously in the present moment because they are more prone to sensation-seeking and lack inhibitory responses (Marks \& Gelder, 1966). But mindfulness can increase their capacity to regulate their emotions better and reduce the tendency for impulsive behaviors. Franco et al. (2016) conducted mindfulness training on adolescents and successfully reduced their level of impulsivity. They suggest that mindful adolescents focus more on the present moment, ruminate less and have more positive emotions, therefore reducing involvement in impulsive behaviours. These are all results of better emotion regulation. Another study on college students conducted by Roos et al. (2015) also found that the relationship between mindfulness and impulsive behaviour related to drinking alcohol was mediated by motives related to mood regulation. Mindful students who did not judge or act reactively to their present moment experiences would not judge the positive or negative experiences they felt, which reduced their tendency to cope by consuming alcohol excessively. This study was conducted on college students, several of whom were no longer adolescents, but there is a possibility that the same mediating relationships will be found in adolescents, as suggested by Franco et al. (2016). Therefore, emotion regulation may mediate the relationship between the mindfulness and impulsivity of adolescents.

Our study intends to establish whether emotion regulation can indeed facilitate this relationship in high school students. It will investigate the effect of mindfulness on impulsivity through emotion regulation as a mediator amongst high school students. To date, only 


\section{Figure 1}

Theoretical Model of Mindfulness and Impulsivity, Mediated by Emotion Regulation

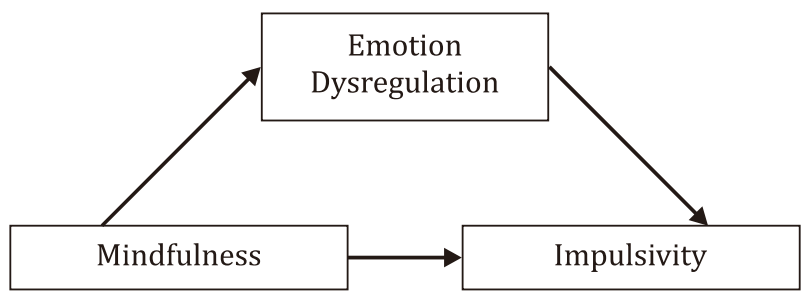

a few studies have researched these three variables amongst adolescents in Indonesia. We hypothesized that there will be a mediating effect of emotion regulation on the mindfulness and impulsivity of high school students.

\section{Method}

\section{Design and Participants}

The research participants were 390 active high school students from Indonesia, aged 15-18 $(\mathrm{M}=16.17, \mathrm{SD}=0.71)$, including 127 males and 263 females. The majority were from DKI Jakarta (77.20\%). The percentage of the participants who had attended public high school was $74.40 \%$, while $25.60 \%$ had attended private high school. They were recruited using a convenience sampling method, through an online questionnaire. The parents of the subjects gave permission for them to participate in the study by completing informed consents before the questionnaires were distributed.

\section{Instruments}

The dependent variable in the study was impulsivity, measured by the Barratt Impulsiveness Scale 11 (BIS-11) (Patton et al., 1995). BIS-11 consists of 30 items measured on a Likert scale of 1 (never) to 4 (always). The higher the score, the more impulsive the individual. BIS-11 has three dimensions: attentional impulsiveness, motor impulsiveness, and non-planning impulsiveness. This study used a version of BIS-11 that had been translated into Indonesian in a previous study by Nurida and Widyasari (2020) and which had a reliability coefficient of 91 .

The independent variable was mindfulness, measured by the Mindfulness Attention Awareness Scale (MAAS) developed by Brown and Ryan (2003). This consists of 15 items which measure mindfulness as a unidimensional variable, using a Likert scale of 1 (always) to 6 (never). The higher the MAAS score, the more mindful the individual. A version of MAAS that had also been translated into Indonesian in a previous study by Nurida and Widyasari (2020), with a reliability coefficient of .92 .

The study mediator was emotion regulation, measured by the Difficulties in Emotion Regulation Scale (DERS) developed by Gratz and Roemer (2004). This measures dysregulation in emotion, with higher scores on the scale meaning that individuals are more likely to dysregulate their emotions. DERS initially had 35 items, but 
after trials, the version used in this study consisted of 32 items. DERS uses a Likert scale of 1 (never) to 5 (always) and comprises six dimensions: nonacceptance, goals, impulse, awareness, strategies, and clarity. It had been translated into Indonesian and used in a previous study by Sukriananda (2016). Two trials were conducted to observe its statistical properties, indicating a reliability coefficient of .94 .

\section{Procedures}

This study was conducted through an online survey using Google Forms. The questionnaire consisted of the three instruments and informed consent. The consents were for both parents and students; the participants were informed of the aim of the study and its ethical aspects. Individuals would only participate in the study if they completed the informed consent.

Multiple regression was used as the statistical technique in order to analyze whether or not a variable mediated the relationship between dependent and independent variables. The mediation analysis was performed using the PROCESS v.3.4 program of Hayes in SPSS 25. Model number four in the PROCESS program was used to conduct the mediation analysis with one mediator.

\section{Results}

Descriptive analyses of the participants were first run. Most were from the science field $(68.70 \%)$ and the remainder from social studies (28.70\%), languages (1.80\%), and other streams $0.80 \%$ of students were from international schools, who were learning both science and social studies subjects). The participants were aged 15 to 18, with most aged 16 (53.60\%). $15.90 \%$ of the participants were aged $15,28.50 \%$
17, and $2.10 \%$ aged 18 . Most $(64.40 \%$ ) were in gradeXI.

Table 1 outlines the descriptive analyses of the research data. Mindfulness had a minimum score of 37 and maximum of 85 . The average score was 61.85, with standard deviation of 8.82 . Emotion regulation was then measured by the dysregulation of emotions, with a minimum score of 46 and a maximum of 135 . The average was 88.68 , with standard deviation of 18.48 . Finally, impulsivity had the minimum score of 44 and a maximum of 88, with an average of 65.89 and standard deviation of 7.63 .

Some comparative analyses were also made to compare the mindfulness, emotion regulation, and impulsivity between participants with different demographics. No differences in impulsivity were found between different genders, ages, grades, schools, or streams. However, female participants $(\mathrm{M}=62.66, \mathrm{SD}=$ 8.77) scored significantly higher on mindfulness compared to their male counterparts $(M=60.18$, $\mathrm{SD}=8.72), \mathrm{t}(388)=-2.62, \mathrm{p}=.009$. No differences in mindfulness were found in any other characteristics. With regard to emotion dysregulation, the results show that female participants $(\mathrm{M}=$ 90.22 , SD = 18.46) were not able to regulate their emotions better than the males $(\mathrm{M}=85.48, \mathrm{SD}=$ 18.20), $\mathrm{t}(388)=-2.34, \mathrm{p}=.017$. Differences in emotion dysregulation were also found in relation to school grade, as determined by one-way ANOVA, $F(2,387)=3.86, p=.022$. A Tukey post hoc test revealed that emotion dysregulation was significantly higher in grade XII $(\mathrm{M}=93.25, \mathrm{SD}=$ 18.01) participants compared to those in grade XI $(\mathrm{M}=86.94, \mathrm{SD}=18.16)$. Emotion dysregulation in other comparison groups did not differ significantly. 
Table 1

Descriptive Analyses of the Research Data

\begin{tabular}{lcccc}
\hline Variable & Min & Max & Mean & SD \\
\hline Mindfulness & 37 & 85 & 61.85 & 8.82 \\
Emotion dysregulation & 46 & 135 & 88.68 & 18.48 \\
Impulsivity & 44 & 88 & 65.89 & 7.63
\end{tabular}

Table 2.

Correlations between Variables

\begin{tabular}{clccc}
\hline No. & Variables & 1 & 2 & 3 \\
\hline 1 & Mindfulness & 1 & & \\
2 & Emotion dysregulation & $-.43^{* *}$ & 1 & \\
3 & Impulsivity & $-.49^{* *}$ & $.47^{* *}$ & 1 \\
\hline Note: ${ }^{* *} p<.01$ & &
\end{tabular}

\section{Figure 2}

Mediating Effect of Emotion Dysregulation on the Relationship between Mindfulness and Impulsivity

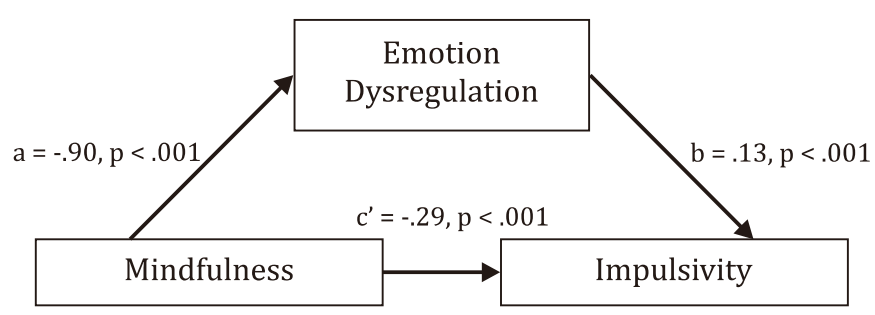

Furthermore, before conducting the mediation test, bivariate correlation was performed using Pearson's Product Moment (see Table 2). The results of the correlation show that mindfulness $(\mathrm{M}=61.85, \mathrm{SD}=8.82)$ had $\mathrm{a}$ significant negative correlation with emotion dysregulation $(\mathrm{M}=88.68, \mathrm{SD}=18.48), \mathrm{r}(388)=$ $.43, \mathrm{p}<.01$ ). It also had a significant negative correlation with impulsivity $(\mathrm{M}=65.89$, $\mathrm{SD}=$ 7.63), $\mathrm{r}(388)=-.49, \mathrm{p}<.01)$. These results show that a high level of dysregulation of emotion and impulsivity was correlated with worse mindfulness capacity. On the other hand, dysregulation of emotion had a significant positive correlation with impulsivity, $\mathrm{r}(388)=.47, \mathrm{p}<.01$, showing that a high level of dysregulation of emotion is correlated with a high level of impulsivity.

Mediation analysis was then conducted using the PROCESS v.3.4 macro to answer the research hypothesis. Mindfulness was found to have a significant direct effect on the decrease in 
impulsivity $\left(c^{\prime}=-.29, \mathrm{t}(387)=-7.5, \mathrm{p}<.001,95 \%[-\right.$ $0.37,-0.22])$. Regarding the indirect effect, it was found to significantly affect impulsivity after mediation by emotion regulation $(\mathrm{ab}=-.11$, BootSE $=0.02$, BootCI 95\% $[-0.16,-0.07])$. The results show that emotion regulation partially mediated the relationship between the mindfulness and impulsivity of high school students, meaning the research hypothesis was accepted.

\section{Discussion}

The research results supported the hypothesis, as it was found that emotion regulation mediated the relationship between the mindfulness and impulsivity of high school students. The results show that students who had good mindfulness skills would also have good emotion regulation, thus reducing impulsivity. Before this study, little research has discussed the effect of these mindfulness, emotion regulation, and impulsivity on high school students in Indonesia. A positive effect of mindfulness and emotion regulation on high school students' impulsivity was found in this study.

The results are supported by the findings of previous studies, in which it was found that mindful individuals could understand, manage, and regulate their emotions more effectively (Roemer et al., 2015; Roos et al., 2015). Impulsive individuals usually have difficulty managing negative emotions, so the increase in emotion regulation would help control the impulses that trigger impulsive behaviors (Park \& Dhandra, 2017). The results of this study can be explained by the fact that mindfulness, which helps people focus on the present moment, reduces obsessive rumination and increases the experiences of positive emotions. Both of those components are part of the emotion regulation capacity that could reduce adolescents' involvement in impulsive tendencies and behaviors (Franco et al., 2016).

Another explanation for the results is that mindfulness can reduce impulsivity through emotion regulation from the reduction of experiential avoidance. Mindful individuals experience less experiential avoidance, or the reluctance to process and be in contact with distressing internal experiences (Peters et al, 2011). The same process occurs in mindful adolescents, as they process negative emotions better as mindfulness has taught them the skill of accepting unpleasant feelings, not rejecting them. Acceptance of unpleasant emotions is the first step in using an effective emotion regulation strategy (Gratz \& Roemer, 2004). Adolescents can use healthier coping strategies because they can observe more of the changes happening around them and reject maladaptive thoughts. The use of healthier coping strategies will also reduce adolescents' tendency to use impulsive coping strategies such as avoidance (Peters et al., 2011).

It was found that the mediating effect of emotion regulation was only partial, because mindfulness was also found to reduce impulsivity directly. Upon closer inspection, the direct effect of mindfulness on impulsivity was greater than the effect of mindfulness on impulsivity mediated by emotion regulation. These results show that emotion regulation is not strong enough to mediate the relationship between mindfulness and impulsivity in adolescents. One of the explanations for this is that emotion regulation has similar components to mindfulness and impulsivity.

Several measurements of mindfulness and emotion regulation have been found to have overlapping aspects, especially those of recog- 
nizing and accepting internal experiences (Coffey et al., 2010). Mindfulness plays a role in increasing the awareness and acceptance of emotion, similar to emotion regulation capacity. Mindful adolescents have clearer awareness and focus on the present moment, so they observe more of their surrounding experiences. This capacity increases the information processed by them, and they become more aware of the feelings and emotions they experience. The ability to be aware of emotions is important in controlling impulsive actions (Gratz \& Roemer, 2004). At the same time, effective emotion regulation strategy also starts with acceptance. In order to regulate emotions effectively, adolescents need to clearly be aware of and recognize the emotions they feel. Adolescents will then accept those emotions and be able to manage their impulses and choose a flexible and effective regulation strategy for the situation in question (Gratz \& Roemer, 2004).

Moreover, emotion regulation also emphasizes impulse control when people are faced with unpleasant experiences (Gratz \& Roemer, 2004). This is another similar element to mindfulness. Mindful individuals observe their distressing experiences without judgment, and are able to control their impulses because they do not act reactively (Coffey et al., 2010). They understand that they need to only accept the distressing experiences and not reject them. Individuals with good emotion regulation are also capable of similar reactions, as they are more able to control their impulses and redirect their attention towards goal-directed behaviors (Gratz \& Roemer, 2004). Therefore, mindfulness and emotion regulation could play a similar role in impulsivity in adolescents.

Impulsivity also has similar components to emotion regulation. The theoretical definition of emotion regulation emphasizes the control of impulses (Gratz \& Roemer, 2004).

Effective regulation emphasises the understanding and acceptance of unpleasant emotions, rather than changing or avoiding them. Adolescents with good emotion regulation skills will not have difficulty in controlling their impulses and taking goal-directed actions. On the other hand, impulsive adolescents will have difficulty regulating their negative and positive emotions, and will act impulsively in managing them (Cyders et al., 2007; Whiteside \& Lynam, 2001). Less impulsive adolescents probably already have a better emotion regulation capacity and are able to manage their negative and positive emotions well. Some of those overlapping mechanisms between impulsivity and emotion regulation could explain why emotion regulation is not strong enough to fully mediate the relationship between mindfulness and impulsivity in adolescents.

Another similar component shared by impulsivity and emotion regulation is related to attention and focus. Individuals who have difficulty in managing their emotions and impulsivity also have difficulties focusing on tasks (Gratz \& Roemer, 2004; Patton et al., 1995). Less impulsive adolescents are probably already able to keep their attention on a task, which lessens the tendency to act without thinking. There is the possibility that individuals are more prone to acting without thinking when they are often faced with negative emotions or have difficulty in facing them (Sperry et al., 2016). Less impulsive adolescents are probably able to face those negative emotions, so are able to think more of the consequences before acting. Some of the overlapping mechanisms of impulsivity and emotion regulation might explain why emotion regulation does not fully mediate the relationship in adolescents. 
The results also indicate two interesting differences between mindfulness and emotion regulation related to certain demographics. It was found that female adolescents were more mindful than males. This is consistent with findings from previous research, in which female participants reported higher mindfulness compared to male ones (Alispahic \& Hasanbegovic-Anic, 2017; Kang et al., 2018). This was probably because females observe their surroundings and details better than their male counterparts (Alispahic \& Hasanbegovic-Anic, 2017). They also tend to experience more negative emotions, hence the possibility that they observe their internal experiences more than males do (Kang et al., 2018).

It was also found that female adolescents had more difficulty regulating their emotions compared to males. This is also supported by previous findings, which found that female adolescents had more difficulty regulating their emotions than male adolescents (Bender et al., 2012; McRae et al., 2008; Neumann et al., 2010). Girls in the adolescent period tend to experience more negative emotions and also find it more difficult to regulate these (Bender et al., 2012; Kang et al., 2018). This is perhaps because boys find it easier to use emotion regulation strategies than girls, who also have less access to effective emotion regulation strategies (Bender et al, 2012). Girls also have more difficulty accepting their negative emotions compared to boys (Neumann et al., 2010).

Participants in higher grade XII were also found to have more difficulty in regulating their emotions compared to those in grade XI. This result was unexpected, because previous studies have found that the ability to regulate emotions increases with age during adolescence
(Zimmermann \& Iwanski, 2014). However, the result of this study could perhaps be explained by the low number of grade XII participants compared to those in grade XI. Further study could be conducted on the differences in emotion regulation between school grades.

This study has found that emotion regulation successfully mediates the relationship between mindfulness and impulsivity. Mindfulness, which increases the ability to be aware at the present moment, will increase adolescents' ability to process and manage the emotions they feel (Cooper et al., 2003; Murphy \& MacKillop, 2012; Peters et al., 2011; Schreiber et al., 2012). They will be able to accept their negative emotions better and use healthy emotion regulation strategies to manage these (Schreiber et al,, 2012). Mindfulness also increases attention to and awareness of the present moment, so adolescents will be able to observe their emotions without responding reactively (Levesque \& Brown, 2007). More mindful adolescents will not act reactively towards unpleasant experiences because they will be more capable of accepting them, which in turn reduces the tendency to act impulsively. Therefore, through emotion regulation, mindfulness can reduce adolescents' habit of acting impulsively, which will have positive impacts on their academic achievement and problem behavior at school.

This study is not without limitations. First, it only covers psychological factors, and does not include social factors that could affect impulsivity. Other social factors, such as family, parenting styles, and friendship, can also have an effect on adolescents and should be studied further (Hansen, 2017). Second, the study only measures impulsivity in one dimension. Certain aspects of impulsivity may explain further the interaction 
between emotion regulation and mindfulness. In addition, the study also has not researched in more depth whether the effect of mindfulness would be different with regard to different components of impulsivity (motor, attentional, and planning). The limitations of this study can be suggestions for future research.

\section{Conclusion}

The study has found that emotion regulation mediates the relationship between the mindfulness and impulsivity of high school adolescents in
Indonesia. However, the effect is only partial, because emotion regulation shares several overlapping components with mindfulness and impulsivity. However, this finding can explain the fact that adolescents with a higher capacity for mindfulness will have better emotion regulation, hence a better ability to control their impulses. Future research could also expand on our results further by analyzing the impact of social factors on adolescents' impulsivity and considering aspects of impulsivity in more detail about mindfulness.]

\section{References}

Aini, D. K., Stück, M., Sessiani, L. A., \& Darmuin, D. (2021). How do they deal with the Pandemic? The effect of secure attachment and mindfulness on adolescent resilience. Psikohumaniora: Jurnal Penelitian Psikologi, 6(1), 103-116. https://doi.org/10.21580/pjpp.v6i1.6857

Alispahic, S., \& Hasanbegovic-Anic, E. (2017). Mindfulness: Age and gender differences on a Bosnian sample. Psychological Thought, 10(1), 155-166. https://doi.org/10.5964/psyct.v10i1.224

Bender, P. K., Reinholdt-Dunne, M. L., Esbjørn, B. H., \& Pons, F. (2012). Emotion dysregulation and anxiety in children and adolescents: Gender differences. Personality and Individual Differences, 53(3), 284-288. https://doi.org/10.1016/j.paid.2012.03.027

Brown, K. W., \& Ryan, R. M. (2003). The benefits of being present: Mindfulness and its role in psychological well-being. Journal of Personality and Social Psychology, 84(4), 822-848. https://doi.org/10.1037/0022-3514.84.4.822

Brown, K. W., Ryan, R. M., \& Creswell, J. D. (2007). Mindfulness: Theoretical foundations and evidence for its salutary effects. Psychological Inquiry, 18(4), 211-237. https://doi.org/10.1080/10478400701598298

Carsley, D., Khoury, B., \& Heath, N. L. (2018). Effectiveness of mindfulness interventions for mental health in schools: a Comprehensive meta-analysis. Mindfulness, 9(3), 693-707. https://doi.org/10.1007/s12671-017-0839-2

Coffey, K. A., \& Hartman, M. (2008). Mechanisms of action in the inverse relationship between mindfulness and psychological distress. Complementary Health Practice Review, 13(2), 79-91. https://doi.org/10.1177/1533210108316307

Coffey, K. A., Hartman, M., \& Fredrickson, B. L. (2010). Deconstructing mindfulness and constructing mental health: Understanding mindfulness and its mechanisms of action. Mindfulness, 1, 235253. https://doi.org/10.1007/s12671-010-0033-2

Cooper, M. L., Wood, P. K., Orcutt, H. K., \& Albino, A. (2003). Personality and the predisposition to engage in risky or problem behaviors during adolescence. Journal of Personality and Social Psychology, 84(2), 390-410. https://doi.org/10.1037/0022-3514.84.2.390 
Cyders, M. A., Smith, G. T., Spillane, N. S., Fischer, S., Annus, A. M., \& Peterson, C. (2007). Integration of impulsivity and positive mood to predict risky behavior: Development and validation of a measure of positive urgency. Psychological Assessment, 19(1), 107-118. https://doi.org/10.1037/1040-3590.19.1.107

D'Acremont, M., \& Van Der Linden, M. (2005). Adolescent impulsivity: Findings from a community sample. Journal of Youth and Adolescence, 34(5), 427-435. https://doi.org/10.1007/s10964-005-7260-1

Dunning, D. L., Griffiths, K., Kuyken, W., Crane, C., Foulkes, L., Parker, J., \& Dalgleish, T. (2018). Research Review: The effects of mindfulness-based interventions on cognition and mental health in children and adolescents - a meta-analysis of randomized controlled trials. Journal of Child Psychology and Psychiatry, 60(3), jcpp.12980. https://doi.org/10.1111/jcpp.12980

Fawzia, R. G. T. (2019). Peran impulsivitas terhadap ketidakjujuran akademik pada mahasiswa fakultas $x$ di universitas $x$. Universitas Sriwijaya.

Franco, C., Amutio, A., López-González, L., Oriol, X., \& Martínez-Taboada, C. (2016). Effect of a mindfulness training program on the impulsivity and aggression levels of adolescents with behavioral problems in the classroom. Frontiers in Psychology, 7(SEP), 1-8. https://doi.org/10.3389/fpsyg.2016.01385

Gecaite-Stonciene, J., Saudargiene, A., Pranckeviciene, A., Liaugaudaite, V., Griskova-Bulanova, I., Simkute, D., Naginiene, R., Dainauskas, L. L., Ceidaite, G., \& Burkauskas, J. (2021). Impulsivity Mediates Associations Between Problematic Internet Use, Anxiety, and Depressive Symptoms in Students: A Cross-Sectional COVID-19 Study. Frontiers in Psychiatry, 12, 1-8. https://doi.org/10.3389/fpsyt.2021.634464

Gómez-Galán, J., Martínez-López, J. Á., Lázaro-Pérez, C., \& Sarasola Sánchez-Serrano, J. L. (2020). Social networks consumption and addiction in college students during the COVID-19 pandemic: Educational approach to responsible use. Sustainability, 12(18), 7737. https://doi.org/10.3390/su12187737

Gratz, K. L., \& Roemer, L. (2004). Multidimensional assessment of emotion regulation and dysregulation: Development, factor structure, and initial validation of the difficulties in Emotion Regulation Scale. Journal of Psychopathology and Behavioral Assessment, 26(1), 41-54. https://doi.org/10.1023/B:JOBA.0000007455.08539.94

Harden, K. P., \& Tucker-Drob, E. M. (2011). Individual differences in the development of sensation seeking and impulsivity during adolescence: Further evidence for a dual systems model. Developmental Psychology, 47(3), 739-746. https://doi.org/10.1037/a0023279

Kang, Y., Rahrig, H., Eichel, K., Niles, H. F., Rocha, T., Lepp, N. E., Gold, J., \& Britton, W. B. (2018). Gender differences in response to a school-based mindfulness training intervention for early adolescents. Journal of School Psychology, 68, 163-176. https://doi.org/10.1016/j.jsp.2018.03.004

Kepala Pusat Informasi dan Humas Kementerian Kominfo. (2014, February 18). Riset Kominfo dan UNICEF mengenai perilaku anak dan remaja dalam menggunakan internet. Kominfo.Go.Id. https://kominfo.go.id/content/detail/3834/siaran-pers-no-17pihkominfo22014-tentangriset-kominfo-dan-unicef-mengenai-perilaku-anak-dan-remaja-dalam-menggunakaninternet/0/siaran_pers

Khurana, A., Romer, D., Betancourt, L. M., \& Hurt, H. (2018). Modeling trajectories of sensation seeking and impulsivity dimensions from early to late adolescence: Universal trends or distinct subgroups? Journal of Youth and Adolescence, 47(9), 1992-2005. https://doi.org/10.1007/s10964-018-0891-9 
King J. S. (2020). Sad mood, emotion regulation, and response inhibition. Journal of Cognitive Psychology, 32(5-6), 573-579. https://doi.org/10.1080/20445911.2020.1777418

Korponay, C., Dentico, D., Kral, T. R. A., Ly, M., Kruis, A., Davis, K., Goldman, R., Lutz, A., \& Davidson, R. J. (2019). The effect of mindfulness meditation on impulsivity and its neurobiological correlates in healthy adults. Scientific Reports, 9(1), 11963. https://doi.org/10.1038/s41598-019-47662$\mathrm{y}$

Lesmana, T. (2017). Hubungan antara mindfulness dan pembelian impulsif pada remaja perempuan yang melakukan shopping online. Psibernetika, 10(2), 81-91. https://doi.org/10.30813/psibernetika.v10i2.1044

Levesque, C., \& Brown, K. W. (2007). Mindfulness as a moderator of the effect of implicit motivational self-concept on day-to-day behavioral motivation. Motivation and Emotion, 31(4), 284-299. https://doi.org/10.1007/s11031-007-9075-8

Lozano, J. H., Gordillo, F., \& Pérez, M. A. (2014). Impulsivity, intelligence, and academic performance: Testing the interaction hypothesis. Personality and Individual Differences, 61-62, 63-68. https://doi.org/10.1016/j.paid.2014.01.013

Luberto, C. M., Cotton, S., McLeish, A. C., Mingione, C. J., \& O’Bryan, E. M. (2014). Mindfulness Skills and Emotion Regulation: the Mediating Role of Coping Self-Efficacy. Mindfulness, 5(4), 373-380. https://doi.org/10.1007/s12671-012-0190-6

Marks, I. M., \& Gelder, M. G. (1966). Fundamentals of human neuropsychology. British Journal of Psychiatry, 112(483), 211-212. https://doi.org/10.1192/bjp.112.483.211-a

McRae, K., Ochsner, K. N., Mauss, I. B., Gabrieli, J. J. D., \& Gross, J. J. (2008). Gender differences in emotion regulation: An fMRI study of cognitive reappraisal. Group Processes \& Intergroup Relations, 11(2), 143-162. https://doi.org/10.1177/1368430207088035

Merrell, C., \& Tymms, P. B. (2001). Inattention, hyperactivity and impulsiveness: Their impact on academic achievement and progress. British Journal of Educational Psychology, 71(1), 43-56. https://doi.org/10.1348/000709901158389

Murphy, C., \& MacKillop, J. (2012). Living in the here and now: Interrelationships between impulsivity, mindfulness, and alcohol misuse. Psychopharmacology, 219(2), 527-536. https://doi.org/10.1007/s00213-011-2573-0

Neumann, A., van Lier, P. A. C., Gratz, K. L., \& Koot, H. M. (2010). Multidimensional assessment of emotion regulation difficulties in adolescents using the difficulties in Emotion Regulation Scale. Assessment, 17(1),138-149. https://doi.org/10.1177/1073191109349579

Nurida, U., \& Widyasari, P. (2020). Impulsivitas siswa sekolah menengah: Peran mindfulness dan selfcontrol.Jurnal Psikologi Insight, 4(1), 1-14. https://doi.org/10.17509/insight.v4i1.24603

Park, H. J., \& Dhandra, T. K. (2017). Relation between dispositional mindfulness and impulsive buying tendency: Role of trait emotional intelligence. Personality and Individual Differences, 105, 208212. https://doi.org/10.1016/j.paid.2016.09.061

Patton, J. H., Stanford, M. S., \& Barratt, E. S. (1995). Factor structure of the barratt impulsiveness scale. $\begin{array}{llll}\text { Journal of Clinical } & \text { Psychology, }\end{array}$ https://doi.org/10.1002/1097-4679(199511)51:6<768::AID-JCLP2270510607>3.0.C0;2-1

Peters, J. R., Erisman, S. M., Upton, B. T., Baer, R. A., \& Roemer, L. (2011). A preliminary investigation of the relationships between dispositional mindfulness and impulsivity. Mindfulness, 2(4), 228235. https://doi.org/10.1007/s12671-011-0065-2 
Rahmawati, A., \& Asyanti, S. (2017). Fenomena perilaku agresif pada remaja dan penanganan secara psikologis. Prosiding SEMNAS Penguatan Individu Di Era Revolusi Informasi.

Ratulangi, A. G., Kairupan, B. H. R., \& Dundu, A. E. (2021). Adiksi internet sebagai salah satu dampak negatif pembelajaran jarak jauh selama masa pandemi COVID-19. Jurnal Biomedik: JBM, 13(3), 251-258. https://doi.org/10.35790/jbm.13.3.2021.31957

Robbins, R. N., \& Bryan, A. (2004). Relationships between future orientation, impulsive sensation seeking, and risk behavior among adjudicated adolescents. Journal of Adolescent Research, 19(4), 428-445. https://doi.org/10.1177/0743558403258860

Roemer, L., Williston, S. K., \& Rollins, L. G. (2015). Mindfulness and emotion regulation. Current Opinion in Psychology, 3, 52-57. https://doi.org/10.1016/j.copsyc.2015.02.006

Romer, D. (2010). Adolescent risk taking, impulsivity, and brain development: Implications for prevention. Developmental Psychobiology, 52(3), 263-276. https://doi.org/10.1002/dev.20442

Roos, C. R., Pearson, M. R., \& Brown, D. B. (2015). Drinking motives mediate the negative associations between mindfulness facets and alcohol outcomes among college students. Psychology of Addictive Behaviors, 29(1), 176-183. https://doi.org/10.1037/a0038529

Salmoirago-Blotcher, E., Druker, S., Meleo-Meyer, F., Frisard, C., Crawford, S., \& Pbert, L. (2019). Beneficial effects of school-based mindfulness training on impulsivity in healthy adolescents: Results from a pilot randomized controlled trial. Explore, 15(2), 160-164. https://doi.org/10.1016/j.explore.2018.07.003

Sari, F., \& Handayani, N. S. (2019). Kontro diri dan pembelian impulsif pakaian pada remaja penggemar K-Pop. Jurnal Psikologi, 12(2), 179-188. https://doi.org/10.35760/psi.2019.v12i2.2442

Schreiber, L. R. N., Grant, J. E., \& Odlaug, B. L. (2012). Emotion regulation and impulsivity in young adults. Journal of Psychiatric Research, 46(5), 651-658. https://doi.org/10.1016/j.jpsychires.2012.02.005

Soler, J., Elices, M., Pascual, J. C., Martín-Blanco, A., Feliu-Soler, A., Carmona, C., \& Portella, M. J. (2016). Effects of mindfulness training on different components of impulsivity in borderline personality disorder: Results from a pilot randomized study. Borderline Personality Disorder and Emotion Dysregulation, 3(1), 1. https://doi.org/10.1186/s40479-015-0035-8

Sperry, S. H., Lynam, D. R., Walsh, M. A., Horton, L. E., \& Kwapil, T. R. (2016). Examining the multidimensional structure of impulsivity in daily life. Personality and Individual Differences, 94, 153-158. https://doi.org/10.1016/j.paid.2016.01.018

Spinella, M., \& Miley, W. M. (2003). Impulsivity and academic achievement in college students. College Student Journal, 37(4), 545-549.

Stanford, M. S., Mathias, C. W., Dougherty, D. M., Lake, S. L., Anderson, N. E., \& Patton, J. H. (2009). Fifty years of the Barratt Impulsiveness Scale: An update and review. Personality and Individual Differences, 47(5), 385-395. https://doi.org/10.1016/j.paid.2009.04.008

Suhendar, S. S. (2019). Hubungan adiksi internet dengan perilaku impulsif pada siswa/i SMP dan SMA J di Citeureup tahun 2019. Universitas Tarumanagara.

Sukriananda, R. R. (2016). Hubungan regulasi emosi dengan civility di konteks media sosial pada remaja. Universitas Indonesia.

Valiente, C., Eisenberg, N., Spinrad, T. L., Haugen, R., Thompson, M. S., \& Kupfer, A. (2013). Effortful control and impulsivity as concurrent and longitudinal predictors of academic achievement. The Journal of Early Adolescence, 33(7), 946-972. https://doi.org/10.1177/0272431613477239 
Vanzin, L., Mauri, V., Valli, A., Pozzi, M., Presti, G., Oppo, A., Ristallo, A., Molteni, M., \& Nobile, M. (2020). Clinical effects of an ACT-Group Training in children and adolescents with attentiondeficit/hyperactivity disorder. Journal of Child and Family Studies, 29(4), 1070-1080. https://doi.org/10.1007/s10826-019-01546-x

Vigil-Colet, A., \& Morales-Vives, F. (2005). How impulsivity is related to intelligence and academic achievement. The Spanish Journal of Psychology, 8(2), 199-204. https://doi.org/10.1017/S1138741600005072

Whiteside, S. P., \& Lynam, D. R. (2001). The five factor model and impulsivity: Using a structural model of personality to understand impulsivity. Personality and Individual Differences, 30(4), 669-689. https://doi.org/10.1016/S0191-8869(00)00064-7

Williams, A. D., \& Grisham, J. R. (2012). Impulsivity, emotion regulation, and mindful attentional focus in compulsive buying. Cognitive Therapy and Research, 36(5), 451-457. https://doi.org/10.1007/s10608-011-9384-9

Zimmermann, P., \& Iwanski, A. (2014). Emotion regulation from early adolescence to emerging adulthood and middle adulthood: Age differences, gender differences, and emotion-specific developmental variations. International Journal of Behavioral Development, 38(2), 182-194. https://doi.org/10.1177/0165025413515405 